\title{
STYLISTICS GENETIC ANALYSIS ON POETRY HENDAK TINGGI? AND HENDAK BAHAGIA??? WRITTEN BY BUNG USMAN AS A PICTURE OF INDONESIAN SOCIETY IN JAPANESE ERA
}

\author{
By: \\ Yosi Wulandari \\ PBSI FKIP UAD \\ yosi.wulandari@pbsi.uad.ac.id
}

\begin{abstract}
ABSTRAK
Puisi sebagai salah satu jenis karya sastra merupakan karya ekspresif wujud penyampai segala rasa. Secara pendokumentasian sejarah pun, puisi dapat menjadi salah satu wadah yang menyimpan catatan sejarah. Pemanfaatan tanda bahasayang digunakan dalam karya sastra merupakan bentuk performansi komunikasi yang digunakan pengarang untuk menyampaikan pesan tertentu. Penyampaian pesan tersebut dilakukan dengan memanfaatkan aspekstilistika sebagai wujud performansi kebahasaan. dalam Hal inilah yang menjadi menarik untuk selalu dikaji dan ditemukan catatan-catatan sejarah dari berbagai sastra masa lampau, salah satunya puisi di zaman Jepang.Indonesia menjadi sebuah negara yang berdaulat pun tidak bisa terlepas dari perkembangan sastra. Bahkan, sastra dapat mencatat dengan baik perjuangan bangsa serta sastra digunakan untuk alat perjuangan dalam meraih kemerdekaan. Zaman Jepang ditemukan dua kelompok sastrawan, yaitu sastrawan yang mendukung Jepang dan melawan Jepang. Bung Usman sebagai salah satu sastrawan yang melawan Jepang menggunakan puisi sebagai bentuk penolakan dan perlawan terhadap Jepang. Menganalisis gaya sastrawan secara indvidual dapat menemukan karakter bahasa sastrawan dan mencerminkan kondisi masyarakat di Zaman Jepang. Berdasarkan hasil analisis data dan pembahasan, Bung Usman memiliki gaya yang khas dalam penulisan puisi di zaman Jepang dengan gaya dominan lewat puisinya dan puisi Bung Usman pun menggambarkan kondisi masyarakat Indonesia yang kebingungan dan tidak tahu hendak melakukan apa sehingga membiarkan kesewenangan Jepang sekaligus menggambarkan keingan masyarakat melawan atau berjuang mendapatkan kemerdekaan Indonesia.
\end{abstract}

Kata Kunci: Stilistika Genetis, Puisi, Bung Usman, Zaman Jepang,

\begin{abstract}
Poetry as one type of literature is a form of expressive works conveys any sense. By documenting the history, poetry can be the way that holds the record of history. Utilization of sign language used in the literature is a form of performance communication of authors to convey a particular message. Messages delivery is done by utilizing stylistics aspects as a form of linguistic performance. It is interesting to be studied and discovered the records of various literature in the past, one of them is poems in Japanese era. Indonesia became a sovereign state could not be separated from the development of literature. In fact, the literature can be recorded with both national struggle and literature used for the implements in the struggle for freedom. There are two groups of letters in Japan era, namely writers who support Japan and against Japan. Bung Usman as one of the writers who oppose Japan uses poetry as a form of rejection and the fight against Japan. Analyzing the literary style individually can find literary language character and reflects the condition of society in the era
\end{abstract}


of Japan. Based on the results of the data analysis and discussion, Bung Usman has a distinctive style of writing poetry at the era of Japan with the dominant specific style effects and through his poetry Bung Usman describes the condition of the Indonesian people are confused and do not know what to do so let the tyranny of Japan It also describe the society against or fight for Indonesian independence.

Keywords: Stylistics Genetic, Poetry, Bung Usman, Japan Era

\section{INTRODUCTION}

Literature work is the result of the creation of author copyright or message to be conveyed to the reader. Righteously, language is a way of literature in conveying intent. In fact, the literary language was considered too "deform" plain language in a variety ways. As part of the literary language literature intensified, compacted, as a telescopes, withdrawn, even overturned for a particular purpose.

Literature language is a language that 'foreign made', and as 'exile', the everyday world as well suddenly become unfamiliar (Eagleton, 2006: 4). However, we realize that literature is the work of "creative" or "imaginative". Ricoeur calls "the world of masterpiece" is the world that offers something new. So, to get the meaning of a word we have to do the "new ways" to perceive and relate to reality, which we find to use unusual words (Sugiharto, 1996: 108). Based on this view can be stated that the meaning of language in literature is more likely to performative tend to demand to do something different.

Bung Usman as a literary writer in Japanese Era opposite of the Japanese government. Poetry of his work has been recorded as the history of Indonesia in anthology of Kesusasteraan Indonesia di Masa Jepang by HB Jassin. Jassin (2013: 7) states that the fruit of life is painting from a soul and viewed from a consciousness. Thus, the turbulence of Bung Usman and his friends have to enlighten the people of Indonesia for not persuaded by Japanese propaganda. 
In connection with the use of language in the description of literature on the history of the nation, Stylistics analysis is an approach that can be used as a tool to analyze poetry. Stylistics demanded that the understanding of literary works continuing with language comprehension, and also that even approaches the study of the technique is a definite step towards the understanding of literature. Most critics tend to take shortcuts and interpretation of literary works in the process of moral and ideological context, without considering any linguistic texture of any linguistic texture (Hough in Sugiarti, (2010: 555). Stylistics as typical literary language will have its own uniqueness when compared to the language of communication everyday. Stylistics is a language that has been created and even engineered to represent the idea of letters.

Generally, Stylistics divided into genetic and descriptive. Stylistics genitive reviewing style of literary works specifically to get certain effects, the study is a form (how to shape) style and what effects caused by its use. This effect is based on the situation style in literature because they layout style in literature that determine the meaning and effect. Meanwhile, descriptive Stylistics is the overall style of language as an expression of psychiatric power contained in a language (langue), namely morphological, syntactic, and semantic.

Based on this concept, basically a stylistic analysis of literary works is to analyze the style of language specifically to get certain effects, which form or forms of language styles and effects by users. The effect will appear based on the situation in the style of literary works are influenced by the location of the style. Thus, each element in a literary work is a functional element so that each element has a meaning that can be analyzed. Therefore, in this analysis aims to describe (1) Style of Language Bung Usman use in Hendak Tinggi? and 
Hendak Bahagia ???; (2) Description of Indonesian Society Condition in Japanese Era.

\section{METHODOLOGY RESEARCH}

This study uses descriptive study of Stylistics genetic. The object of research is two poems Bung Usman, Hendak Tinggi? and Hendak Bahagia??? Poetry Bung Usman was taken from the anthology of Kesusasteraan Indonesia di Masa Jepang. Bung Usman made the object is to find an individual style of Bung Usman in creating the effect cynicism in his poetry. Data collection techniques is the engineering documentation and identified based on sound style, word style, sentence, and discourse. The data were analyzed based on the concept of sound style, word style, sentence style, and the style of discourse.

\section{DISCUSSION}

\section{Style of Language Bung Usman use in Hendak Tinggi? and Hendak Bahagia ???}

Stylistic Genetic is stylistic which discussing the language of a literature style individually. Research Bung Usman style in his work, namely Hendak Tinggi / and Hendak Bahagia ??? is a stylistic genetic analysis. Two works have been selected for both these poems contained in the anthology of Kesusasteraan Indonesia di Masa Jepang and both use the word "want" and question mark as a symbol of the meaning. Moreover, both poems have a very high cynical taste that needs to be limited to a depth of study.

Assessment of stylistic genetic aims to find a style of Bung Usman on his work at the era of Japan. Observations style Bung Usman use on Hendak Tinggi poetry? and Hendak Bahagia ??? seen that Bung Usman deliberately use such force it to meet poetic elements, get a certain effect, and raises the intensity of meaning. 
Kalau masih di bawah, di tanah,

Here's the style can be described Bung akan musnah,

Usman on Hendak Tinggi? and Hendak

Bahagia ???

sebab pelempar bom mengintai mangsa,

dengan bomnya dari udara.....

\section{Puisi 1}

Hendak Tinggi?

Mau tinggi,

Di muka bumi???

Panjat kelapa

Sampai ke puncak!!!
Alangkah tinggi
Di muka bumi!!!!

\section{Puisi II}

\section{Hendak Bahagia???}

Hendak bahagia, hidup sentosa, bebas dari bahaya?

Terbang ke awan, ke angkasa, mengatasi kapal udara!!!!
Based on the those two quotes poetry, sound style used by Bung Usman concerned poetic effect, have a rhythm that causes lyrical sonority. Bung Usman deliberately using poetry, figurative sound, orchestration (sound of music in the poem). Poetry is used Bung Usman does not follow a specific pattern, in both these poems there is a repetition of sounds at the end. The second poem shows Bung Usman wear ephony orchestra, namely the combination of melodious sound. Usage efoni prominently indicate that the expression of unpleasant circumstances. In addition, the use of punctuation exclamation and question and also provide high effect and low tones in the sentence. This suggests Bung Usman deliberately used the orchestration efoni and high tones 
and lace to effect outpouring of feeling as seen in the above quote poetry.

Word style in this study can not be separated from its relationship with the sentence because the word is meaningless without a sentence. However, the style of the gain function words in sentences. Style that stands out from the second word of the poem is the style of imagery and figurative language. This image style look with the use of the word oil, aircraft, clouds, sky, ground, bombs, and so on. All the words used in both poems provide color in poetry Bung Usman. Prominent figurative language used is apofasis style, that style of language used by the author to convey something that you lack the element of contradiction. For example, the words of the poem I "Mau tinggi, di muka bumi???/ Panjat kelapa sampai ke puncak!!!! Alangkah tinggi di muka bumi!!!."The three stanzas of the poem looks like give solution, but it is actually mocking the action . Besides silepsis style and allegory, silepsis is density construction style form followed by the words which are not similar and allegory as the development of metaphor symbolic. This style is reflected in both the second stanza poem "Terbang ke awan, ke angkasa, mengatasi kapal udara!!!!". The next style is the style of the epithet, a phrase descriptive to replace the name of a person, animal, or an object. The second poem using the phrase "Pelempar Bom", this phrase is used to replace the word of Japanese.

Sentence and discourse style in poetry Bung Usman condensed by means of rhetoric. Rhetoric is the dominant means of command and rhetorical questions. The second verse of the poem is seen questioning something with sarcasm and then answer with a loud cry. It looks very prominent on the use of the exclamation mark that more than two in both poetry. The visible effects of Bung Usman style is as if as an orator who want to fight the Japanese. Additionally, the style cynicism 
is very prominent in the tone of Bung

Usman poems. Cynicism is essentially the same as irony, but harder. It is indirectly describe the bitterness heart Bung Usman had in Japan Era.

\section{Description of Indonesian Society}

\section{Condition in Japanese Era}

Literary work is a masterpiece of human creative present as a messenger and news. Righteously, poets were present to convey the taste of composition in order to give an idea of how the conditions or situations that occur. Ratna (2013: 210) states that the analogy, in literature both as a writer or readers are both able to give birth to a literary competence, that is universal knowledge that gives access to the understanding of literary texts. Therefore, poetics licensed is basically a poet freedom to obey certain rules in the use of language. In addition to this, the analysis is done on the basis Stylistics / assumption that literary language has a noble task. Language as a medium of communication literature has beauty and meaning. Without the beauty of the language, it becomes meaningless. The beauty of literature most of the affected language. The ability to process writers language will create a distinctive beauty in literature. In other words, Endraswara (2003: 72) states that language is a special vehicle for literary expression. Thus, the author language aims to explore notions so as to achieve the aesthetic aspect of the work they produce.

Analysis of stylistic genetic provides a clear illustration of how the style of Bung Usman who cynical about government at the time of the Japanese invaded Indonesia with political propaganda. Bung Usman persuasion style invites people of Indonesia struggling with a great word parable. Thus, the analysis can also describe how the condition of the people of Indonesia in Japanese era, including the following. The first poem illustrates the 
doubts and confusion facing precarious situations because of wrongdoing by the Japanese. The second poem is showing people who hate, revenge, and the disobedient to the tense situation by the actions of the Japanese occupation. The second poem is also invites people of Indonesia should dare to fight against the Japanese at that time.

\section{CONCLUSION}

Based on the results of the data analysis and discussion in the previous section, there are two things that can be inferred. First, Bung Usman has a distinctive style of writing poetry at the era of Japan with the dominant specific style effects in both the use of force sound, words, sentence, and discourse. Secondly, through his poetry Bung Usman describes the condition of the Indonesian people are confused and do not know what to do so let the tyranny of Japan. It also describe the society against or fight for Indonesian independence.

\section{BIBLIOGRAPHY}

Eagleaton, Terry. 2006. Teori Sastra Sebuah Pengantar Komprehensif. Yogyakarta : Jalasutra.

Endraswara, Suwardi. 2003. Metodologi Penelitian Sastra Epistemologis Model Teori dan Aplikasi. Yogyakarta: Pustaka Widyatama.

Jassin, H.B. 2013. Kesusasteraan Indonesia di Masa Jepang. Yogyakarta: Pustaka Jaya.

Ratna, Nyoman Kutha. 2013. Stilistika: Kajian Puitika Bahasa, Sastra, dan Budaya. Yogyakarta: Pustaka Pelajar.

Sugiarti. 2010. "Kajian Stilistika Novel Nayla Karya Djenar Maesa Ayu dan Petir Karya Dewi Lestari”. Jurnal Artikulasi Vol.9 No.1 Februari 2010, hal. 555-573. 